\section{Управление миражами}

Немногие видели миражи в природе, но почти все знают о них: в определенной ситуации в атмосфере перед взором человека появляются необычные картины - далекие леса, города и горы, которых поблизости нет и в помине. Впечатление тем сильнее, чем в более сложных и отличающихся от окружающей обстановки условиях находится тот, кому доводится все это созерцать.

Можно ли управлять миражами? Скорее, нет - слишком сложна природа этого явления и слишком многие обстоятельства определяют его конкретные очертания. K тому же воспроизведение игры сил природы (не путать с лазерным шоу!) чересчур сложно и слишком затратно. Последнее особенно важно, когда имеешь дело с той местностью, где миражи - частые «гости»: это пустыни и безлюдные пространства со сложными природно-климатическими условиями (которые и характерны для России) .

Поэтому ответ на сформулированное в заголовке колонки утверждение вполне ожидаем и однозначен - управлять миражами и бессмысленно, и дорого (есть более прагматичные и важные дела).

Увы, когда дело касается управления современной российской экономикой, данное утверждение не представляется столь очевидным. Это касается, прежде всего, понимания объекта управления теми, кому доверено выполнять роль регулятора (ов). К их числу относятся не только Центральный банк РФ, но и многие органы исполнительной власти, прежде всего, федерального уровня (что вполне закономерно в условиях «унитарного федерализма»).

Регулятор пытается воздействовать на ту экономику, которая существует в его воображении и которая во многом сродни упомянутым выше миражам в безлюдной и неуютной для проживания местности. В частности, предполагается, что системой простых и «действенных» мер, таких как уменьшение денежной массы в экономике, а также повышение процентных ставок, можно не только уменьшить инфляцию, но и обеспечить создание условий и предпосылок для дальнейшего экономического роста (см. статью А. О. Баранова).

Увы, данный мираж неуправляем и не реагирует на подобные меры и шаги. Напротив, вместо экономического роста (или хотя бы стабилизации) экономика с неизбежностью переходит в состояние стагфляции (сочетание растущей инфляции и падения производства).

Тезис о том, что в непростые экономические времена (во многом вытекающие из нашего славного коммунистического прошлого) все в равной степени должны переживать трудности, и социальный мир и спокойствие важны как никогда, во внимание не принимается. Скорее, наоборот, мир, основанный на видимости социального согласия, трансформируется в свою явную противоположность. Прибыль в экономике страны растет опережающими темпами, «как следствие недостаточного роста оплать труда». В полную силу проявляет себя один из постулатов марксистской политэкономии о стремлении капитала к увеличению «нормы эксплуатации рабочей силы» (статья Н. И. Суслова).

Эффективные меры социальной поддержки, направленные на сдерживание чрезмерного роста прибыли, могли бы смягчить падение потребления и позволили бы увеличить сберегаемые активы. Но развитию событий в данном направлении противостоит устойчивый мираж, созданный не только отсутствием мер по сдерживанию роста прибыли, но и прямыми действиями Правительства РФ по экономии на самых незащищенных слоях населения.

Тот мираж, которым пытается управлять регулятор (ы), в малой степени напоминает и то, что реализуют другие страны в схожих условиях. Современное контролируемое монетарное стимулирование гораздо более прагматично и, соответственно, более действенно. Не промежуточные цели - такие как «таргетирование инфляции», а уровень занятости и динамика доходов населения являются одними из основных ориентиров в развитых странах мира.

Мир миражей, созданный в экономике России, гораздо шире и многообразнее, чем реализация «простых и очевидных» мер выхода из кризиса. Это во многом касается регулирования ведущих отраслей российской экономики - прежде всего, энергетики и минеральносырьевого сектора. Здесь действия органов исполнительной власти основаны на удивительной, не зависящей от времени и обстоятельств, приверженности к выполнению одних и тех же функций на протяжении десятков лет (невзирая на изменение экономических и политических условий). Так, Минприроды РФ всеми силами и способами стремится обеспечить расширенное воспроизводство минерально-сырьевой базы (в то время как в других странах все больше ориентируются на рост социальной ценности природно-ресурсного потенциала), Минэнерго РФ - к управлению потоками электрической энергии (при почти полном невмешательстве в дела нефтяных и, тем более, газовых компаний), Минфин РФ - к формированию бюджета текущего года (без учета того, в какой мере и как это затрагивает интересы бизнеса и его деятельность по воспроизводству основных активов) (статья В. А. Крюкова). 
Мир миражей очень неустойчив, при небольшом изменении какоголибо из параметров внешней среды меняется вся картина - и, как правило, самым непредсказуемым образом.

Вне мира миражей живет реальный бизнес - предприятия и компании, которые производят, строят, принимают на себя риски реализации нелогичных, с точки зрения регулятора, решений. Однако возможности и потенциал реального сектора не беспредельны - уровень старения основных активов в промышленности значительно превышает критически допустимые значения, неуклонно растут издержки, устаревает номенклатура выпускаемой продукции, снижается ее качество.

Решение всех этих злободневных и наболевших проблем требует вдумчивости, понимания особенностей процесса материального производства, высокой степени открытости и стремления быть эффективным.

Применение большинства рычагов и механизмов регулирования современных экономических процессов предполагает постоянное соотнесение результатов их действия с динамикой материально-производственных показателей и с ними связанных измерителей. А мир миражей основан на прожектах, видимости управляемости огромной (пока еще) экономикой и слабой заинтересованности в эффективности. В этом мире наиболее важно освоение, выполнение, расходование и равнение на промежуточный показатель (например, уровень инфляции или денежной массы в экономике).

Мир миражей живет ожиданием чуда - отскока цен на нефть, появления новых «тигров», которые «потянут» за собой мировую экономику (и нас с ней заодно), чудес и озарений науки (в виде наноматериалов, например) .

Будничная, прагматичная и разносторонняя деятельность (с учетом мнений, опыта и навыков самых разных специалистов) плохо согласуется с подобным миром.

Кризис - не только время очищения, но и время преодоления. Преодолевать и одолевать российские промышленники и деловые люди умели и умеют. Сумеют и в этот раз. 